\title{
Pengaruh Model Pembelajaran Quantum Berbantuan Media Tiga Dimensi Terhadap Hasil Belajar IPA
}

\author{
Ni Km. Winda1 ${ }^{*}$, I K Dibia² ${ }^{2}$ I K Sudarma ${ }^{3}$ \\ 1,2,3 Jurusan Pendidikan Guru Sekolah Dasar (PGSD), Universitas Pendidikan Ganesha, Singaraja, Indonesia.
}

\author{
A R T I C L E I N F O \\ Article history: \\ Received 16 February \\ 2018 \\ Received in revised form \\ 09 March 2018 \\ Accepted 19 April 2018 \\ Available online 25 May \\ 2018 \\ Kata Kunci: \\ hasil belajar, media tiga \\ dimensi, quantum \\ Keywords: \\ learning outcomes, three \\ dimensional media, \\ quantum
}

\begin{abstract}
A B S T R A K
Penelitian ini bertujuan untuk mengetahui perbedaan yang signifikan hasil belajar IPA antara kelompok siswa yang dibelajarkan dengan model pembelajaran Quantum berbantuan media tiga dimensi dan kelompok siswa yang dibelajarkan dengan model pembelajaran konvensional pada siswa kelas V SD Gugus I Kecamatan Sukasada Kabupaten Buleleng Tahun Pelajaran 2017/2018. Jenis penelitian eksperimen semu dengan rancangan non-equivalent post-test only control group design. Populasi penelitian ini adalah seluruh siswa kelas V SD Gugus I Kecamatan Sukasada Kabupaten Buleleng Tahun Pelajaran 2017/2018 yang berjumlah 175 orang. Pengambilan sampel menggunakan teknik random sampling yaitu simple random sampling dengan cara undian. Sampel penelitian yaitu siswa kelas V SD Negeri 4 Pancasari yang terpilih sebagai kelompok eksperimen dan siswa kelas V SD Negeri 2 Wanagiri yang terpilih sebagai kelompok kontrol. Data yang diperoleh dianalisis dengan menggunakan statistik deskriptif dan statistik inferensial. Hasil penelitian menunjukkan bahwa hasil analisis uji-t diperoleh thitung lebih besar dibandingkan dengan ttabel (thitung
\end{abstract} $6,48>$ ttabel 2,008). Hal ini berarti bahwa terdapat perbedaan yang signifikan hasil belajar IPA antara kelompok siswa yang dibelajarkan dengan model pembelajaran Quantum berbantuan media tiga dimensi dan kelompok siswa yang dibelajarkan dengan model pembelajaran konvensional pada siswa kelas V SD Gugus I Kecamatan Sukasada Kabupaten Buleleng Tahun Pelajaran 2017/2018. Dengan demikian, dapat disimpulkan bahwa model pembelajaran Quantum berbantuan media tiga dimensi berpengaruh positif terhadap hasil belajar IPA siswa kelas V SD di Gugus I Kecamatan Sukasada Kabupaten Buleleng Tahun Pelajaran 2017/2018

\begin{abstract}
A B S T R A C T
This research aimed at finding out the significant difference of science learning outcomes among the group of students who were taught by Quantum learning model aided three dimensional media and the group of students who were taught by conventional learning model on fifth grade students at Cluster I Sukasada Sub-district, Buleleng Regency in Academic Year 2017/2018. This research was a quasi-experimental research with the non-equivalent post-test only control group design. The population of this research was the entire fifth grade students at Cluster I Sukasada Subdistrict, Buleleng Regency in Academic Year 2017/2018 which amounted to 175 people. The sample of this research was fifth grade students of SD Negeri 2 Wanagiri which was selected as the experimental group and fifth grade students of SD Negeri 2 Wanagiri which was selected as the control group. The obtained data were analyzed by using descriptive statistical analysis and inferential statistical analysis. The result of this research showed there was a significant difference of science learning outcomes among the group of students who were taught by Quantum learning model-aided three-dimensional media and the group of students who were taught by conventional learning model on fifth grade students at Cluster I Sukasada Sub-district, Buleleng Regency in Academic Year 2017/2018. Therefore, it can be concluded that Quantum learning model aided three dimensional media has a positive effect on fifth grade students' learning outcomes at Cluster I Sukasada Subdistrict Buleleng Regency in Academic Year 2017/2018.

Copyright (C) Universitas Pendidikan Ganesha. All rights reserved.
\end{abstract}

Corresponding author.

E-mail addresses: kmwinda21@yahoo.com (Ni Km. Winda) 


\section{Pendahuluan}

Pembelajaran dalam abad ke 21 harus lebih dari sekedar menghafal fakta dan memahami konsep umum materi pelajaran yang mengarah pada pembentukan siswa yang terdidik dan cerdas. Untuk dapat membangun siswa yang cerdas serta mampu menyesuaikan diri dengan tuntutan perkembangan ilmu pengetahuan abad ke 21 ini, maka hal yang mendesak untuk dilakukan sekarang adalah menata kembali sistem pembelajaran (Jufri, 2017). Terkait dengan penataan sistem pembelajaran, maka guru harus berusaha menggeser paradigma pengelolaan pembelajaran dari yang dahulunya lebih berpusat pada guru (teacher cantered) menjadi lebih berpusat pada siswa (student centered).

Paradigma baru seperti ini, bermakna bahwa pembelajaran harus diubah menjadi pembelajaran yang lebih bertumpu pada kemampuan pengembangan inteleketual siswa dan mendorong siswa untuk membangun pemahaman dan pengetahuan sendiri melalui pengalaman langsung. Pembelajaran ini dapat berlangsung dengan dukungan berbagai aspek seperti teman sebaya, guru, lingkungan, serta media pembelajaran. Dalam hal ini, kondisi dan suasana belajar yang kondusif dan menyenangkan akan tercipta. Pencapaian tujuan tersebut dapat terwujud melalui pembelajaran yang inovatif.

Pembelajaran inovatif adalah "pembelajaran yang dikemas guru atas dorongan gagasan baru untuk melakukan langkah-langkah belajar dengan metode baru sehingga memperoleh kemajuan dalam proses dan hasil belajar". Memperhatikan dan menerapkan hal tersebut, sangat baik jika dilakukan oleh setiap guru yang melakukan proses pembelajaran di SD. Susanto (2016:92) menyatakan bahwa,"guru sebagai ujung tombak dalam pelaksanaan pendidikan merupakan pihak yang sangat berpengaruh dalam proses pembelajaran". Dalam proses pembelajaran di kelas mempunyai tujuan yang bersifat transaksional, artinya diketahui secara jelas dan operasional oleh guru dan siswa. "Tujuan tercapai jika siswa memperoleh hasil belajar seperti yang diharapkan di dalam proses belajar mengajar" (Bundu, 2006:17). Riastini, (2016:87) menyatakan bahwa, hasil belajar merupakan "hasil yang diperoleh setelah melakukan kegiatan belajar". Salah satu mata pelajaran yang harus dicapai hasil belajarnya yaitu IPA.

IPA merupakan ilmu pengetahuan yang sangat penting keterkaitannya dengan kehidupan seharihari. Asmarayasa (2013) berpendapat bahwa, "pendidikan IPA menekankan pada pemberian pengalaman langsung dan kegiatan praktis untuk mengembangkan kompetensi agar siswa memahami alam sekitar secara ilmiah". Pembelajaran IPA harus bisa menitikberatkan pada suatu proses pengalaman langsung bagi diri siswa. Pengalaman langsung yang dimaksud adalah pembelajaran IPA di SD dilakukan dengan penyelidikan sederhana dan bukan hafalan terhadap kumpulan konsep IPA. Dengan pembelajaran yang demikian akan mampu munumbuhkan sikap ilmiah siswa. Selain itu pembelajaran akan mencerminkan kegiatan yang kondusif dan menyenangkan.

Namun, fakta yang ditemukan di sekolah pembelajaran IPA masih belum sesuai dengan harapan, berdasarkan hasil wawancara, observasi dan pencatatan dokumen yang dilakukan di Gugus I Kecamatan Sukasada Kabupaten Buleleng Tahun Pelajaran 2017/2018 terkait dengan pembelajaran IPA. Didapat hasil wawancara dari 8 (delapan) orang guru IPA di kelas V pada tanggal 23 dan 24 November 2017 yaitu sebagai berikut.

Pertama, dari pihak guru tidak pernah mengajar dengan menggunakan model pembelajaran. Kedua, siswa tidak mampu memahami sepenuhnya materi yang diberikan guru dikarenakan tidak semua materi yang diberikan bersifat hafalan tetapi memerlukan suatu penemuan langsung. Ketiga, hasil belajar siswa yang masih rendah belum mencapai KKM dalam pembelajaran IPA disebabkan oleh faktor tertentu seperti perhatian siswa yang kurang dalam belajar, media pembelajaran yang kurang mendukung dan pembelajaran yang diberikan kurang menarik minat siswa.

Setelah melakukan wawancara dengan guru kelas V di Gugus I Kecamatan Sukasda Kabupaten Buleleng terkait dengan mata pelajaran IPA, dilanjutkan dengan melakukan observasi pada tanggal 24 dan 25 November 2017 untuk melihat proses pembelajaran IPA yang dilaksanakan oleh guru di dalam kelas. Hasil observasi yang didapat yaitu sebagai berikut. Pertama, siswa masih dititikfokuskan menjadi objek bukan subjek oleh guru. Kedua, materi yang diberikan guru kurang bermakna bagi siswa. Ketiga, suasana di kelas pada saat pembelajaran IPA berlangsung masih terlihat kurang kondusif. Kurang kondusif yang dimaksudkan adalah situasi yang membuat pembelajaran tidak efektif dan menyenangkan.

Selain wawancara dan observasi dilakukan pencatatan dokumen yang telah dilakukan di seluruh SD Gugus I Kecamatan Sukasada Kabupaten Buleleng Tahun Pelajaran 2017/2018. Berdasarkan hasil pencatatan dokumen yang dilakukan di seluruh SD Gugus I Kecamatan Sukasada Kabupaten Buleleng pada tanggal 11 dan 15 Desember 2017 pada mata pelajaran IPA, ditemukan permasalahan yaitu hasil belajar siswa rendah. Hasil belajar IPA siswa rendah dikarenakan faktor berikut. Pertama, pembelajaran IPA belum mencerminkan kegiatan yang bermakna dan menyenangkan. Kedua, guru kurang memperhatikan pentingnya media dalam pembelajaran IPA sehingga guru jarang menggunakan sarana 
pendidikan yang tersedia di sekolah. Ketiga, kurang adanya kegiatan pembelajaran yang lebih menekankan keaktifan siswa. Keempat, siswa kurang berpartisipasi secara aktif dalam pembelajaran.

Hasil belajar IPA siswa kelas V SD Gugus I Kecamatan Sukasada Kabupaten Buleleng Tahun Pelajaran 2017/2018 masih belum optimal karena rata-rata nilai siswa masih belum memenuhi Kriteria Ketuntasan Minimal (KKM). Salah satu upaya yang dapat digunakan untuk mengatasi masalah tersebut yaitu dengan menggunakan model pembelajaran yang dapat memberikan gagasan dan langkah-langkah baru bagi guru dalam memberikan pembelajaran IPA di kelas. Salah satu model yang tepat digunakan agar proses pembelajaran IPA menjadi kondusif dan menyenangkan, serta menitikberatkan pada suatu pengalaman langsung yang dapat memunculkan dimensi keberhasilan belajar yaitu model pembelajaran Quantum. DePorter, dkk (2005:3) menyatakan bahwa, pembelajaran Quantum adalah "pengubahan belajar yang meriah dengan segala nuansanya". Dalam pembelajaran Quantum juga menyertakan segala kaitan interaksi dan perbedaan yang memaksimalkan momen belajar. Kelebihan pembelajaran Quantum berfokus pada hubungan dinamis dalam lingkungan kelas, interaksi yang menjadi landasan dan kerangka untuk belajar. Siswa diberikan kesempatan untuk mengembangkan segala pengetahuan dan keterampilan yang dimiliki dalam proses pembelajaran berlangsung.

DePorter, dkk (dalam Wena, 2009) mengungkapkan pada dasarnya dalam pelaksanaan komponen rancangan pembelajaran Quantum, dikenal dengan singkatan "TANDUR”. Enam langkah pembelajaran tersebut antara lain, 1) tumbuhkan yaitu pada awal kegiatan pembelajaran, pengajar harus berusaha menumbuhkan minat siswa untuk belajar; 2) alami yaitu proses pembelajaran akan lebih bermakna jika siswa mengalami secara langsung materi yang diajarkan; 3) namai yaitu penamaan adalah saatnya untuk mengajarkan konsep, keterampilan, berpikir, dan strategi belajar; 4) demonstrasikan yaitu memberi peluang pada siswa untuk menerjemahkan dan menerapkan pengetahuan mereka ke dalam pembelajaran lain atau ke kehidupan mereka; 5) ulangi yaitu proses pengulangan dalam kegiatan pembelajaran dapat memperkuat koneksi saraf dan menumbuhkan rasa tahu atau yakin terhadap kemampuan siswa; 6) rayakan mengandung makna bahwa pemberian penghormatan pada siswa atas usaha, ketekunan, dan kesuksesannya. Secara sederhana model pembelajaran Quantum menguraikan beberapa metode atau cara-cara baru yang lebih mempermudah dalam melakukan proses belajar mengajar lewat pemanduan seni dan pencapaian-pencapaian yang terarah.

Untuk memaksimalkan penerapan pembelajaran Quantum diperlukan penggunaan media pembelajaran. Media yang dapat digunakan untuk memaksimalkan penerapan model Quantum yaitu media tiga dimensi (3D). Menurut Asyhar (2012:47), media tiga dimensi (3D) yaitu "media yang tampilannya dapat diamati dari arah mana saja dan mempunyai dimensi panjang, lebar, dan tinggi/tebal". Penggunaan media tiga dimensi dapat melibatkan jenis media yang merangsang semua indra dalam proses pembelajaran. Dengan demikian pembelajaran akan menjadi lebih hidup karena aktivitas dan kreativitas siswa sudah berjalan. Sangat tepat jika dalam pembelajaran IPA di SD menerapkan model pembelajaran Quantum berbantuan media tiga dimensi, karena dapat menciptakan kegiatan belajar yang kondusif dan menyenangkan. Dapat membantu siswa dalam memecahkan masalah dengan prosedurprosedur penemuan langsung dalam pembelajaran IPA.

Berdasarkan uraian di atas, maka akan dicoba untuk menerapkan model pembelajaran Quantum berbantuan media tiga dimensi dan melihat pengaruhnya terhadap hasil belajar IPA. Untuk itu diadakan suatu penelitian dengan judul "Pengaruh Model Pembelajaran Quantum Berbantuan Media Tiga Dimensi Terhadap Hasil Belajar IPA Siswa Kelas V SD Gugus I Kecamatan Sukasada Kabupaten Buleleng Tahun Pelajaran 2017/2018".

Tujuan dari penelitian ini adalah untuk mengetahui perbedaan yang signifikan hasil belajar IPA antara kelompok siswa yang dibelajarkan dengan model pembelajaran Quantum berbantuan media tiga dimensi dan kelompok siswa yang dibelajarkan dengan model pembelajaran konvensional pada siswa kelas V SD Gugus I Kecamatan Sukasada Kabupaten Buleleng Tahun Pelajaran 2017/2018.

\section{Metode}

Penelitian ini dilaksanakan di SD Gugus I Kecamatan Sukasada, Kabupaten Buleleng. Penelitian ini mengikuti desain penelitian kuasi eksperimen dengan rancangan non-equivalent post-test only control group design. Berdasarkan rancangan penelitian tersebut, kelompok eksperimen diberikan perlakuan menggunakan model pembelajaran Quantum berbantuan media tiga dimensi. Setelah diberikan perlakuan, selanjutnya kelompok eksperimen diberikan tes akhir. Sedangkan kelompok kontrol tidak diberikan perlakuan atau tetap menggunakan model pembelajaran konvensional, dan kelompok kontrol juga diberikan tes akhir. Kedua hasil dianalisis untuk mengetahui tingkat keberhasilan perlakuan yang diberikan. 
Pelaksanaan penelitian ini terdiri dari tiga tahap, yaitu tahap persiapan, tahap pelaksanaan, dan tahap akhir. Tahap persipan terdiri dari merancang perangkat pembelajaran dan instrumen yang digunakan untuk penelitian, mengonsultasikan perangkat pembelajaran dan instrumen dengan pembimbing dan pakar, menguji instrumen yang digunakan utuk penelitian, melakukan analisis uji instrumen, melakukan revisi uji instrumen. Dan merivisi instrumen penelitian. Pada tahap pelaksanaan dilakukan 7 kali pertemuan untuk memberikan treatment dan 1 kali pertemuan untuk pemberian posttest. Pada tahap ini, pelaksaan pembelajaran kelompok eksperimen menggunakan model pembelajaran Quantum berbantuan media tiga dimensi dan kelompok kontrol menggunakan model pembelajaran konvensional. Melakukan pengamatan untuk melihat pembelajaran yang dilakukan oleh guru pada kelompok eksperimen dan kelompok kontrol. Tahap akhir dilakukan analisis data berdasarkan data hasil belajar dari kelompok eksperimen dan kelompok kontrol, dan menyusun laporan hasil penelitian berdasarkan hasil analisis data.

Populasi dalam penelitian ini adalah siswa kelas V di Gugus I Kecamatan Sukasada yang menggunakan KTSP yang terdiri dari 7 sekolah dengan jumlah seluruh siswa yaitu 175 orang. Untuk mengetahui kesetaraan kemampuan akademik siswa kelas V SD di Gugus I Kecamatan Sukasada. Untuk mengetahui kesetaraan kemampuan akademik siswa kelas V SD di Gugus I Kecamatan Sukasada, maka digunakan nilai hasil belajar IPA semester I diuji kesetaraan dengan menggunakan analisis varian satu jalur (Anava A). Berdasarkan uji kesetaraan, diperoleh Fhitung 0,0016 < Ftabel 2,15. Setelah melakukan uji kesetaraan selanjutnya dilakukan penentuan sampel. Pengambilan sampel menggunakan teknik random sampling dengan cara undian. Setelah diperoleh hasil perhitungan uji kesetaraan, selanjutnya ketujuh SD yang sudah diuji kesetaraannya tersebut dirandom untuk menentukan kelas eksperimen dan kelas kontrol. Dari hasil pengundian ditetapkan kelas V di SD Negeri 4 Pancasari yang berjumlah 29 orang sebagai kelompok eksperimen yang diberikan perlakuan menggunakan model pembelajaran Quantum berbantuan media tiga dimensi dan kelas V SD Negeri 2 Wanagiri yang berjumlah 24 orang sebagai kelompok kontrol dengan belajar seperti biasa secara konvensional.

Data yang dikumpulkan dalam penelitian ini adalah data hasil belajar IPA siswa kelas V. Untuk memperoleh data tentang hasil belajar siswa, digunakan metode tes. Metode tes merupakan "cara memperoleh data yang berbentuk suatu tugas yang harus dikerjakan oleh seseorang atau sekelompok orang yang dites (testee), dan dari tes dapat menghasilkan suatu skor (interval)" (Agung, 2014:92). Dalam penelitian ini, tes ini dipergunakan untuk mengukur hasil belajar IPA siswa baik pada siswa di kelompok eksperimen maupun kelompok kontrol. Tes yang digunakan tes objektif dalam bentuk pilihan ganda.

Tes tersebut diuji coba lapangan dan dianalisis untuk mengetahui tingkat validitas butir, reabilitas, taraf kesukaran dan daya beda tes. Namun, sebelum melakukan uji coba lapangan, dilakukan uji validitas isi oleh pakar di bidang IPA. Berdasarkan uji bakar, diketahui instrumen penelitian tes hasil belajar memiliki kategori sangat tinggi. Tes yang diujicobakan berjumlah 35 item soal yang diberikan kepada 55 testee. Hasil analisis menunjukkan 32 item soal yang valid dengan reliabilitas 0,94 . Hal ini berarti tes yang diujicobakan tergolong sangat tinggi. Hasil tingkat kesukaran butir tes diperoleh 27 butir soal yang memiliki tingkat kesukaran tes sedang dan 8 butir soal yang berada pada tingkat kesukaran mudah. Secara keseluruhan perangkat tes berada pada tingkat kesukaran 0,69 yang artinya kriteria kesukaran sedang. Hasil daya beda, diperoleh 12 butir soal yang berkualifikasi sangat baik, 15 butir soal berkualifikasi baik, 6 butir soal berkualifikasi cukup baik, dan 2 butir soal yang berkualifikasi kurang baik. Berdasarkan perhitungan terhadap 35 butir tes diperoleh daya beda perangkat tes sebesar 0,604, sehingga dapat disimpulkan bahwa perangkat tes hasil belajar IPA memiliki daya beda baik.

Diperoleh 30 item soal yang akan diberikan kepada siswa kelas eksperimen dan kontrol sebagai post-test. Teknik analisis data yang digunakan adalah analisis statistik deskriptif dan analisis statistik inferensial. Analisis statistik deskriptif meliputi mean, median modus, standar deviasi, dan varians. Dalam analisis statisktik inferensial meliputi uji prasyarat analisis data diantaranya uji normalitas sebaran data dan uji homogenitas varians. Dalam pengujian hipotesis menggunakan uji-t.

\section{Hasil dan Pembahasan}

Data penelitian ini adalah skor hasil belajar IPA siswa sebagai akibat dari penerapan model pembelajaran Quantum berbantuan media tiga dimensi pada kelompok eksperimen dan model pembelajaran konvensional pada kelompok kontrol. Rekapitulasi hasil analisis data statistik deskriptif disajikan pada Tabel 1 berikut. 
Tabel 1. Rekapitulasi hasil perhitungan skor hasil belajar IPA siswa

\section{Data Hasil Belajar IPA Siswa}

\begin{tabular}{lll}
\hline Statistik & $\begin{array}{l}\text { Kelompok } \\
\text { Eksperimen }\end{array}$ & $\begin{array}{l}\text { Kelompok } \\
\text { Kontrol }\end{array}$ \\
\hline Mean & 21,93 & 14,87 \\
\hline Median & 23,76 & 14,05 \\
\hline Modus & 24,51 & 12,49 \\
\hline Standar deviasi & 4,81 & 4,29 \\
\hline
\end{tabular}

Kemudian data hasi belajar IPA siswa kelompok eksperimen tersebut disajikan ke dalam kurva bentuk poligon seperti pada gambar 1 .

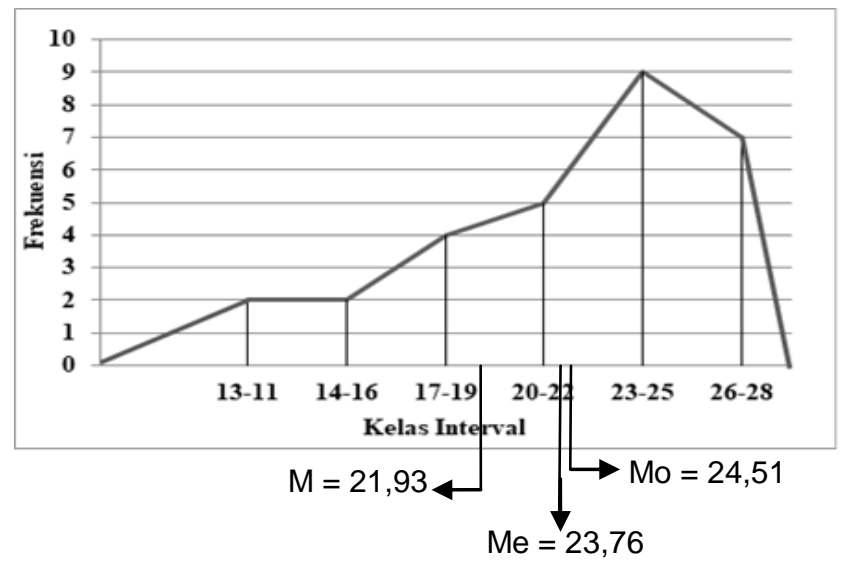

Gambar 1. Poligon hasil belajar siswa kelompok eksnerimen

Gambar 1 tersebut menunjukkan kurva sebaran skor kelompok siswa yang dibelajarkan dengan model pembelajaran Quantum berbantuan media tiga dimensi merupakan kurva juling negatif, karena Mo $>$ Md>M (24,51>23,76>21,93). Hal ini menunjukkan bahwa sebagian besar skor kelompok eksperimen cenderung tinggi. Untuk mengetahui tinggi rendahnya hasil belajar IPA siswa, skor rata-rata hasil belajar dikonversikan dengan menggunakan kriteria rata-rata ideal dan standar deviasi ideal dengan skala lima menunjukkan skor rata-rata hasil belajar IPA berada pada kategori tinggi. Sedangkan data hasil belajar IPA siswa kelompok kontrol dapat disajikan ke dalam bentuk poligon seperti pada Gambar 2 .

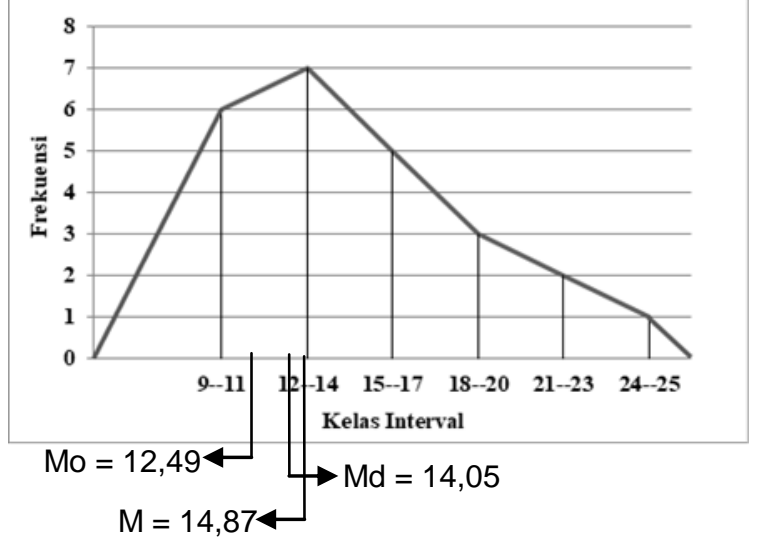

Gambar 2. Poligon data hasil belajar ipa siswa kelompok kontrol

Gambar 2 tersebut menunjukkan kurva sebaran skor kelompok siswa yang dibelajarkan dengan model pembelajaran konvensional merupakan kurva juling positif, karena $\mathrm{Mo}<\mathrm{Md}<\mathrm{M}$ 
$(12,49<14,05<14,87)$. Hal ini menunjukkan bahwa sebagian besar skor kelompok kontrol cenderung rendah. Jika dikonversikan dengan menggunakan kriteria rata-rata ideal dan standar deviasi ideal dengan skala lima menunjukkan skor rata-rata hasil belajar IPA berada pada kategori sedang.

Berdasarkan hasil uji prasyarat analisis diperoleh bahwa data hasil belajar IPA siswa kelompok eksperimen diperoleh $\chi^{2}$ hitung adalah 7,41 dan $\chi^{2}$ tabel adalah 7,815 Hal ini berarti, $\chi^{2}$ hitung hasil belajar IPA kelompok eksperimen lebih kecil dari $\chi^{2}$ tabel sehingga data skor hasil belajar IPA kelompok eksperimen berdistribusi normal. Sedangkan $\chi^{2}$ hitung hasil belajar IPA kelompok kontrol adalah 4,52 dan $\chi^{2}$ tabel adalah 7,815. Hal ini berarti, $\chi^{2}$ hitung hasil belajar IPA kelompok kontrol lebih kecil dari $\chi^{2}$ tabel, sehingga data hasil belajar IPA kelompok kontrol berdistribusi normal.

Setelah melakukan uji normalitas, dilakukan uji homogenitas varians. Uji homogenitas menggunakan uji-F. Hasil perhitungan uji data kedua kelompok tersebut, diperoleh $F_{\text {hitung }}$ dengan $d b$ pembilang $=28$ dan $\mathrm{db}$ penyebut $=23$, didapat $\mathrm{F}_{\text {hitung }}=1,25<\mathrm{F}_{\text {tabel }}=2,00$, varians kelompok eksperimen dan kelompok kontrol adalah homogen. Kemudian dilakukan uji hipotesis untuk mengetahui pangaruh dari model pembelajaran yang diterapkan menggunakan uji-t dengan rumus polled varians. Uji ini dilakukan terhadap data post-test terhadap kelompok eksperimen dan kelompok kontrol. Rangkuman hasil perhitungan uji-t antar kelompok eksperimen dan kontrol disajikan pada Tabel 2.

Tabel. 2 Rangkuman hasil perhitungan uji-t

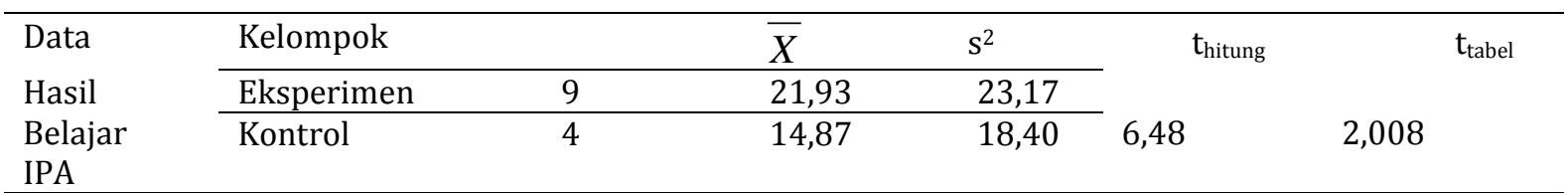

Keterangan :

$\mathrm{N}=$ Jumlah iswa

$\bar{X}=$ Mean

$\mathrm{s}^{2}=$ Varians

Berdasarkan tabel hasil perhitungan uji-t di atas, diperoleh nilai $t_{\text {hitung }}$ lebih besar dari nilai $t_{\text {tabel }}$ ( $t_{\text {hitung }}>\mathrm{t}_{\text {tabel }}$ ), sehingga $\mathrm{H}_{0}$ ditolak atau $\mathrm{H}_{1}$ diterima. Dengan demikian, dapat disimpulkan bahwa terdapat perbedaan yang signifikan hasil belajar IPA antara kelompok siswa yang dibelajarkan dengan model pembelajaran Quantum berbantuan media tiga dimensi dan kelompok siswa yang dibelajarkan dengan model pembelajaran konvensional pada siswa kelas V SD Gugus I Kecamatan Sukasada Kabupaten Buleleng tahun Pelajajaran 2017/2018.

Berdasarkan deskripsi data hasil penelitian, kelompok siswa yang mengikuti pembelajaran Quantum berbantuan media tiga dimensi memiliki hasil belajar kognitif IPA lebih tinggi dibandingan dengan kelompok siswa yang mengikuti pembelajaran konvensional. Rata-rata skor hasil belajar IPA kelompok eksperimen yaitu sebesar 21,93, dan rata-rata skor hasil belajar IPA kelompok kontrol sebesar 14,87. Apabila skor hasil belajar IPA siswa kelompok eksperimen digambarkan dalam grafik poligon, tampak bahwa kurva sebaran data membentuk kurva juling negatif yang berarti bahwa sebagian besar skor siswa cenderung tinggi. Sedangkan pada kelompok kontrol, apabila skor hasil belajar IPA siswa digambarkan dalam grafik poligon tampak bahwa kurva sebaran data membentuk kurva juling positif yang berarti

sebagian besar skor siswa cenderung rendah.

Berdasarkan analisis data menggunakan uji-t diketahui $t_{\text {hitung }}=6,48$ dan $t_{\text {tabel }}=2,008$. Hasil perhitungan tersebut menunjukkan bahwa $t_{\text {hitung }}$ lebih besar dari pada $t_{\text {tabel }}\left(t_{\text {hitung }}>t_{\text {tabel }}\right)$ dapat dikatakan bahwa penelitian ini signifikan. Hal ini berarti terdapat perbedaan yang signifikan hasil belajar IPA antara kelompok siswa yang dibelajarkan dengan model pembelajaran Quantum berbantuan media tiga dimensi dan kelompok siswa yang dibelajarkan dengan model pembelajaran konvensional pada siswa kelas V SD Gugus I Kecamatan Sukasada Kabupaten Buleleng Tahun Pelajaran 2017/2018.

Perbedaan hasil belajar IPA antara kelompok siswa yang dibelajarkan dengan model pembelajaran Quantum berbantuan media tiga dimensi dan kelompok siswa yang dibelajarkan dengan model pembelajaran konvensional pada siswa kelas V SD di Gugus I Kecamatan Sukasada Kabupaten Buleleng Tahun Pelajaran 2017/2018 disebabkan beberapa faktor. Adapun faktor-faktor yang mempengaruhi yaitu sebagai berikut. 
Pertama, model pembelajaran Quantum merupakan suatu inovasi pembelajaran yang dapat memberikan kesempatan kepada siswa untuk menemukan informasi pengetahuan melalui kegiatan yang mengutamakan proses. Pembelajaran Quantum berbantuan media tiga dimensi ini, mampu menghilangkan hambatan-hambatan yang dialami oleh siswa dan guru. Hal tersebut sejalan dengan pendapat Rusman (2016:330) yang menyatakan bahwa "pembelajaran Quantum dapat mengubah semua hambatan belajar yang selama ini dipaksakan untuk terus dilakukan menjadi sebuah manfaat bagi siswa sendiri dan bagi orang lain dengan memaksimalkan kemampuan dan bakat ilmiah dari diri siswa itu sendiri".

Kedua, tahap rancangan pembelajaran Quantum, dikenal dengan singkatan "TANDUR" yaitu kepanjangan dari Tumbuhkan, Alami, Namai, Demonstrasikan, Ulangi, Rayakan yang juga berpengaruh dalam peningkatan hasil belajar siswa. Pada tahap pertama, guru menumbuhkan minat siswa dalam belajar. Tahap tumbuhkan merupakan konsep guru untuk memikat siswa agar tertarik dalam mengikuti pembelajaran dengan memanfaatkan pengalaman siswa. Hal ini sejalan dengan pendapat Sugandika (2013) yang menyatakan bahwa, "guru membuat pertanyaan tentang kemampuan siswa dengan memanfaatkan pengalaman siswa dan mencari tanggapan, manfaat serta komitmen siswa”.

Pada tahap kedua, dalam pembelajaran guru harus memberi pengalaman terhadap pengetahuan yang dibangun siswa sehingga menimbulkan hasrat alami otak untuk menjelajah. Pemberian pengalaman dapat dilakukan melalui kegiatan pengamatan, percobaan, dan berdiskusi LKS. Hal ini sejalan dengan pendapat Susanto (2016:171) yang menyatakan bahwa, "siswa akan mendapat pengalaman langsung melalui pengamatan, diskusi, penyelidikan sederhana”. Tahap ketiga yaitu namai, dengan bantuan guru siswa berusaha menemukan konsep atas pengalaman yang telah dilewati. Hal ini sejalan dengan pendapat Asmarayasa (2013) yang menyatakan bahwa, "namai, yaitu memberi kesempatan kepada siswa untuk memberikan identitas, mengurutkan, dan mendefinisikan suatu konsep dengan pengetahuan yang dimiliki'.

Tahap keempat yaitu demonstrasikan, setelah menemukan konsep, siswa diberikan kesempatan untuk menunjukkan apa yang diketahui (mendomonstrasikan). Hal ini sejalan dengan pendapat Margandhyta (2013) menyatakan bahwa, kegiatan demonstrasi yang dilakukan siswa memberi kesempatan siswa untuk menunjukkan bahwa siswa tahu. Hal ini sekaligus memberi kesempatan siswa untuk menunjukkan tingkat pemahamannya terhadap materi yang dipelajari. Tahap kelima yaitu ulangi, proses pengulangan dalam kegiatan pembelajaran dapat memperkuat koneksi saraf dan menumbuhkan rasa ingin tahu atau yakin dengan kemampuan siswa. Yulianti (2014) menyatakan bahwa, guru dalam mengajar dapat menunjukkan cara yang mudah untuk mengulang materi. Misalnya, dengan memberikan rangkuman yang diajarkan. Tahap keenam yaitu rayakan, adanya penghargaan/reward untuk siswa dapat meningkatkan motivasi siswa untuk belajar, sehingga hasil belajar siswa dapat ditingkatkan.

Ketiga, keterlibatan guru dalam pembelajaran sangat berpengaruh terhadap hasil belajar siswa. Interaksi yang dijalin oleh guru dan siswa akan menimbulkan hubungan yang harmonis dan akan berdampak baik pada hasil akademik siswa. Siswa dan guru dapat beriteraksi satu dengan yang lainnya sehingga terjalin sebuah ikatan di antara mereka. Hal ini sesuai pada "pembelajaran Quantum yang bersandar pada konsep Bawalah dunia mereka ke dunia kita, dan antarkan dunia kita ke dunia mereka" (DePorter, dkk, 2005:6). Artinya, langkah seorang guru dalam kegiatan proses belajar mengajar berlangsung adalah memahami atau memasuki dunia siswa sebagai bagian dalam kegiatan pembelajaran.

Keempat, penggunaan media tiga dimensi sangat membantu siswa dalam proses pembelajaran. Daryanto (2016) menyatakan, media tiga dimensi memberikan pengalaman secara langsung kepada siswa. Hal ini dapat dilihat ketika berlangsungnya kegiatan pembelajaran pada kelompok eksperimen. Ketika siswa melakukan pengamatan dan percobaan dengan media tiga dimensi, siswa menjadi lebih senang dan tertarik mengikuti pembelajaran. Kamayani (2013) menyatakan, peran media tiga dimensi dalam proses pembelajaran dapat menarik perhatian siswa, karena siswa dapat melihat secara langsung, selain itu dengan menggunakan media tiga dimensi dapat lebih cepat dalam menerima proses pembelajaran yang pada gilirannya dapat meningkatkan hasil belajar yang dicapainya

Berbeda halnya dengan model pembelajaran konvensional, dalam pembelajaran guru lebih mendominasi proses pembelajaran sehingga pembelajaran hanya berpusat pada guru (teacher centered). Model pembelajaran konvensional paling sederhana yang sebagian besar digunakan oleh guru. Guru mengendalikan proses pembelajaran dengan metode yang digunakan seperti ceramah, tanya jawab dan penugasan. Temuan ini sesuai dengan penelitian yang dilakukan oleh Setiawan (2015) yang menyatakan bahwa, "pembelajaran konvensional berorientasi pada guru merupakan sistem pendidikan konvensional dimana hampir seluruh proses pembelajaran dikendalikan oleh guru". Rasana (2009) yang menyatakan bahwa dalam pembelajaran konvensional guru yang aktif di kelas dan siswa menjadi pasif, guru memberikan ceramah, tanya jawab, dan tugas untuk siswa. Penjelasan yang diberikan guru masih berorientasi pada buku dan guru jarang mengaitkan materi yang dibahas dengan masalah-masalah nyata 
dalam kehidupan sehari-hari. Selain itu, aktivitas siswa kurang dioptimalkan dan siswa kurang dilatih untuk belajar menemukan suatu informasi pengetahuan. Hal ini mengakibatkan hasil belajar IPA siswa rendah karena proses pembelajaran yang dilakukan kurang bermakna untuk siswa.

Perbedaan tahapan pembelajaran antara model pembelajaran Quantum berbantuan media tiga dimensi dan model pembelajaran konvensional akan memberikan dampak yang berbeda terhadap hasil belajar siswa. Penerapan model pembelajaran Quantum berbantuan media tiga dimensi menyebabkan siswa memilki pengalaman yang bermakna. Siswa akan lebih aktif dan pembelajaran akan mengarahkan siswa untuk menemukan informasi langsung melalui pembelajaran yang menekankan keterampilan prosesnya. Siswa menjadi lebih tertantang untuk belajar dan berusaha menyelesaikan permasalahan IPA yang ditemukan, sehingga siswa lebih memahami materi yang dipelajari. Dengan demikian, hasil belajar IPA siswa yang dibelajarkan dengan model pembelajaran Quantum berbantuan media tiga dimensi lebih baik dibandingkan hasil belajar IPA siswa yang dibelajarkan dengan model pembelajaran konvensional.

\section{Simpulan dan Saran}

Berdasarkan hasil penelitian dan pembahasan, dapat disimpulkan sebagai berikut. Terdapat perbedaan yang signifikan hasil belajar IPA antara kelompok siswa yang dibelajarkan dengan model pembelajaran Quantum berbnatuan media tiga dimensi dan kelompok siswa yang dibelajarkan dengan model pembelajaran konvensional pada siswa kelas V SD Gugus I Kecamatan Sukasada Kabupaten Buleleng Tahun Pelajaran 2017/2018. Hal ini ditunjukkan dari hasil perhitungan uji-t, thitung = 6,48 > ttabel = 2,008 sehingga $\mathrm{H} 0$ ditolak dan $\mathrm{H} 1$ diterima.

Berdasarkan hasil dari penelitian yang telah dilakukan, maka dapat dikemukakan beberapa saran yaitu pertama, agar selalu memotivasi diri untuk belajar sehingga hasil belajar yang maksimal mampu dicapai. Selain itu, disarankan kepada siswa agar lebih aktif menggali pengetahuan sendiri sehingga pengetahuan yang didapat sendiri akan lebih lama untuk diingat. Kedua, bagi guru agar menggunakan model pembelajaran Quantum berbantuan media tiga dimensi khususnya dalam mata pelajaran IPA dan mata pelajaran lain pada umumnya dalam upaya meningkatkan hasil belajar siswa. Saran ini diajukan karena berdasarkan hasil penelitian ditemukan bahwa model pembelajaran Quantum berbantuan media tiga dimensi dapat meningkatkan hasil belajar IPA siswa sekolah dasar. Ketiga, bagi kepala sekolah agar hasil penelitian ini dapat dijadikan pertimbangan mengambil suatu kebijakan untuk membina guru dalam meningkatkan kemampuan mengelola proses pembelajaran. Keempat, bagi peneliti lain yang berminat untuk mengadakan penelitian tentang model pembelajaran Quantum berbantuan media tiga dimensi dalam mata pelajaran IPA maupun mata pelajaran lainnya yang sesuai, hendaknya memperhatikan kendala-kendala yang dialami dalam penelitian ini sehingga mendapatkan hasil penelitian yang lebih sempurna.

\section{Daftar Rujukan}

Agung, A.A. Gede. 2014. Metodologi Penelitian Pendidikan. Yogyakarta: Aditya Media Publishing.

Asmarayasa, K Yogi. 2013. "Pengaruh Model Pembelajaran Kuantum Terhadap Hasil Belajar IPA Siswa Kelas IV di Gugus I Kecamatan Kubutambahan". e-Journal PGSD Universitas Pendidikan Ganesha Jurusan PGSD: Singaraja. Dalam

https://ejournal.undiksha.ac.id/index.php/JJPGSD/article/view/1444/1305(diakses tanggal 2 Januari 2018).

Asyar, Rayandra. 2012. Kreatif Mengembangkan Media Pembelajaran. Jambi: Referensi Jakarta.

Bundu, Patta. 2006. Penilaian Keterampilan Proses dan Sikap Ilmiah Dalam Pembelajaran Sains SD. Jakarta: Departemen Pendidikan Nasional.

Daryanto. 2016. Media Pembelajaran. Yogyakarta: Penerbit Gava Media.

DePorter, Bobbi dkk. 2005. Quantum Teaching: Mempraktikkan Quantum Learning di Ruang-Ruang Kelas. Terjemahan Nilandari. Quantum Learning: Orchestrating Student Success. 2005. Cetakan Ke- 17.

Bandung: Mizan Media Utama.

Jufri, Wahab. 2017. Belajar dan Pembelajaran Sains. Bandung: Pustaka Reka Cipta. 
Kamayani, A Diah. 2013. "Pengaruh Model Pembelajaran Project Based Learning Berbantuan Media Tiga Dimensi Terhadap Hasil Belajar IPA di SD Gugus IX Kecamatan Buleleng". e-Journal PGSD Universitas Pendidikan Ganesha Jurusan PGSD: Singaraja. Dalam https://ejournal.undiksha.ac.id/index.php/JJPGSD/article/view/800 (diakses tanggal 2 Mei 2018).

Margandhyta, M Dewi. 2013. "Pengaruh Model Pembelajaran Quantum Teaching Terhadap Prestasi Belajar IPA Siswa Kelas IV di SD Gugus VI Kecamatan Buleleng". e-Journal PGSD Universitas Pendidikan Ganesha Jurusan PGSD: Singaraja. Dalam https://ejournal.undiksha.ac.id/index.php/JJPGSD/article/view/1234 (diakses tanggal 2 Mei 2018).

Rasana, Raka. 2009. Model-Model Pembelajaran. Singaraja: Universitas Pendidikan Ganesha.

Riastini, Nanci. 2016. Pembelajaran IPA SD. Singaraja: Universitas Pendidikan Ganesha.

Rusman. 2016. Model-Model Pembelajaran Mengembangkan Profesionalisme Guru. Jakarta: Rajawali Pers.

Setiawan, I G Yudi. 2015. "Pengaruh Model Quantum Teaching Terhadap Hasil Belajar IPA Kelas VI di Gugus IV Kecamatan Petang". e-Journal PGSD Universitas Pendidikan Ganesha Jurusan PGSD: Singaraja. Dalam https://ejournal.undiksha.ac.id/index.php/JJPGSD/article/view/6128 (diakses tanggal 2 Januari 2018).

Sugandika, I G Kawit. 2013. ”Pengaruh Model Quantum Teaching Terhadap Pemahaman Konsep IPA Siswa Kelas IV di Gugus VII Kecamatan Buleleng". e-Journal PGSD Universitas Pendidikan Ganesha JurusanPGSD: Singaraja. Dalam http://id.portalgaruda.org/index.php?ref=browse\&mod=viewarticle\&article=105348 (diakses tanggal 2 Januari 2018).

Susanto, Ahmad. 2016. Teori Belajar Pembelajaran di SD. Jakarta: Prenadamedia Group.

Wena, M. 2009. Strategi Pembelajaran Inovatif Kontemporer Suatu Tinjauan Konseptual Operasional. Jakarta: PT Bumi Aksara.

Yulianti, Dina. 2014. "Pengaruh Model Quantum Teaching and Learning dengan Pemanfaatan Media Gambar Terhadap Hasil Belajar IPA Siswa Kelas V SD Negeri di Gugus XI Kecamatan Buleleng". eJournal PGSD Universitas Pendidikan Ganesha Jurusan PGSD: Singaraja. Dalam https://ejournal.undiksha.ac.id/index.php/JJPGSD/article/view/2641 (diakses tanggal 2 Mei 2018) 